\title{
Changes in climate, land use and local conditions drive macrophyte assemblages in a Mediterranean shallow lake
}

\author{
Jorge García-Girón*, Camino Fernández-Aláez, Margarita Fernández-Aláez and Alejandro \\ Nistal-García
}

Group for Limnology and Environmental Biotechnology. Ecology Section. University of León. Campus de Vegazana, 24071 León, Spain.

* Corresponding author: jgarcg21@estudiantes.unileon.es

Received: 20/06/17

Accepted: 11/12/17

\begin{abstract}
Changes in climate, land use and local conditions drive macrophyte assemblages in a Mediterranean shallow lake

Mediterranean shallow lakes are affected by many deterioration processes like eutrophication, land-use changes along its drainage basin and climate change. Aquatic plants are expected to reflect the ecological changes of shallow lakes since they are in close contact with the environmental factors. We assessed the influence of climate, land use and local conditions on macrophyte community changes in Sentiz Lake, a steppe water body located in the northwest of Spain, using long term data of local conditions, satellite imagery, orthophotography and climatic series. We found important changes in the environmental drivers of aquatic macrophyte assemblages (e.g. mean depth, water surface area, shore vegetation, mean annual temperature and grassland coverage). Similarly, we found that aquatic macrophyte growth forms responded to different environmental controlling factors: submerged and floating-leaved hydrophytes responded to local conditions, while big helophytes and small helophytes responded to land use and climate, respectively. Overall, our study suggests that management efforts aimed at preserving aquatic macrophyte assemblages of shallow Mediterranean lakes should focus not only on local conditions of each lake but also on their watersheds and climate. Therefore, this study improves the knowledge of the environmental drivers of aquatic macrophyte assemblages of shallow Mediterranean lakes, incorporating long term data of both physical and biological parameters and providing a basic framework for applying management and conservation strategies in these and other similar ecosystems.
\end{abstract}

Key words: aquatic plants, ecological drivers, eutrophication, macrophytes, Mediterranean lake

\section{RESUMEN}

Los cambios en el clima, los usos del suelo y las características locales determinan la comunidad de macrófitos en una laguna somera mediterránea

Las lagunas mediterráneas sufren procesos de deterioro derivados de la eutrofización, los cambios en los usos del suelo de su cuenca de drenaje y el cambio climático. Es esperable que las plantas acuáticas respondan a los cambios ecológicos al encontrarse en estrecho contacto con los factores ambientales. En este estudio se evalúa la influencia del clima, los usos del suelo y las características locales en los cambios experimentados por la comunidad de macrófitos de la laguna Sentiz, un medio lenítico y de carácter estepario situado en el noroeste de España. Para ello, se han utilizado datos de las características locales, imágenes de satélite, ortofotografías y series climáticas. El estudio reveló la existencia de importantes cambios en los factores ecológicos determinantes de las comunidades de macrófitos, destacando los cambios sufridos en la profundidad media, la superficie del medio palustre, la vegetación higrófila, la temperatura media anual y la cobertura de pastizal. Asimismo, se ha encontrado que la evolución temporal de la cobertura de los hidrófitos sumergidos y con hojas flotantes estuvo determinada por las características locales, mientras que la cobertura de los grandes y pequeños helófitos estuvo definida por los cambios en los usos del suelo y en las condiciones climáticas, respectivamente. Nuestro estudio sugiere que las estrategias de conservación de las comunidades de macrófitos en lagunas someras mediterráneas deben enfocarse no solamente en la 
gestión de las características locales de cada laguna, sino también en la gestión de sus cuencas de drenaje y teniendo en cuenta la evolución climática. En este sentido, nuestros resultados mejoran el conocimiento de los factores ambientales de las comunidades de macrófitos de lagunas someras mediterráneas, incorporando series históricas tanto de las características físico-químicas del ecosistema como de sus comunidades biológicas. Finalmente, se pretende aportar información relevante de los factores determinantes de las comunidades de macrófitos a la hora de implementar estrategias de gestión y conservación de estos y de otros ecosistemas leníticos similares.

Palabras clave: eutrofización, factores ecológicos, laguna mediterránea, macrófitos, plantas acuáticas

\section{INTRODUCTION}

Shallow lakes are especially important ecosystems since they constitute biodiversity islands and hot-spots, supporting high biodiversity, namely invertebrates and aquatic macrophytes (Loh \& Wackernagel, 2004). Human influence has been a primary cause of changes in the structure of biological communities of shallow lakes through induced actions like climate change, eutrophication, biological invasions and land-use changes on their catchment area (Ormerod et al., 2010). In many cases, these direct impacts inter- act synergistically or antagonistically modifying the physical structure of communities and the allochthonous inputs (Bosch et al., 2014).

Climate change is one of the most serious threats for ecosystems and, particularly, for the biodiversity of wetlands and shallow lakes (Parmesan \& Yohe, 2003). Shallow lakes are vulnerable to climate change and thus they can warn us about such changes taking place (Adrian et al., 2009). Besides climate change, Feld et al. (2016) documented other stress factors on macrophyte assemblages such as habitat degradation and land-use changes.

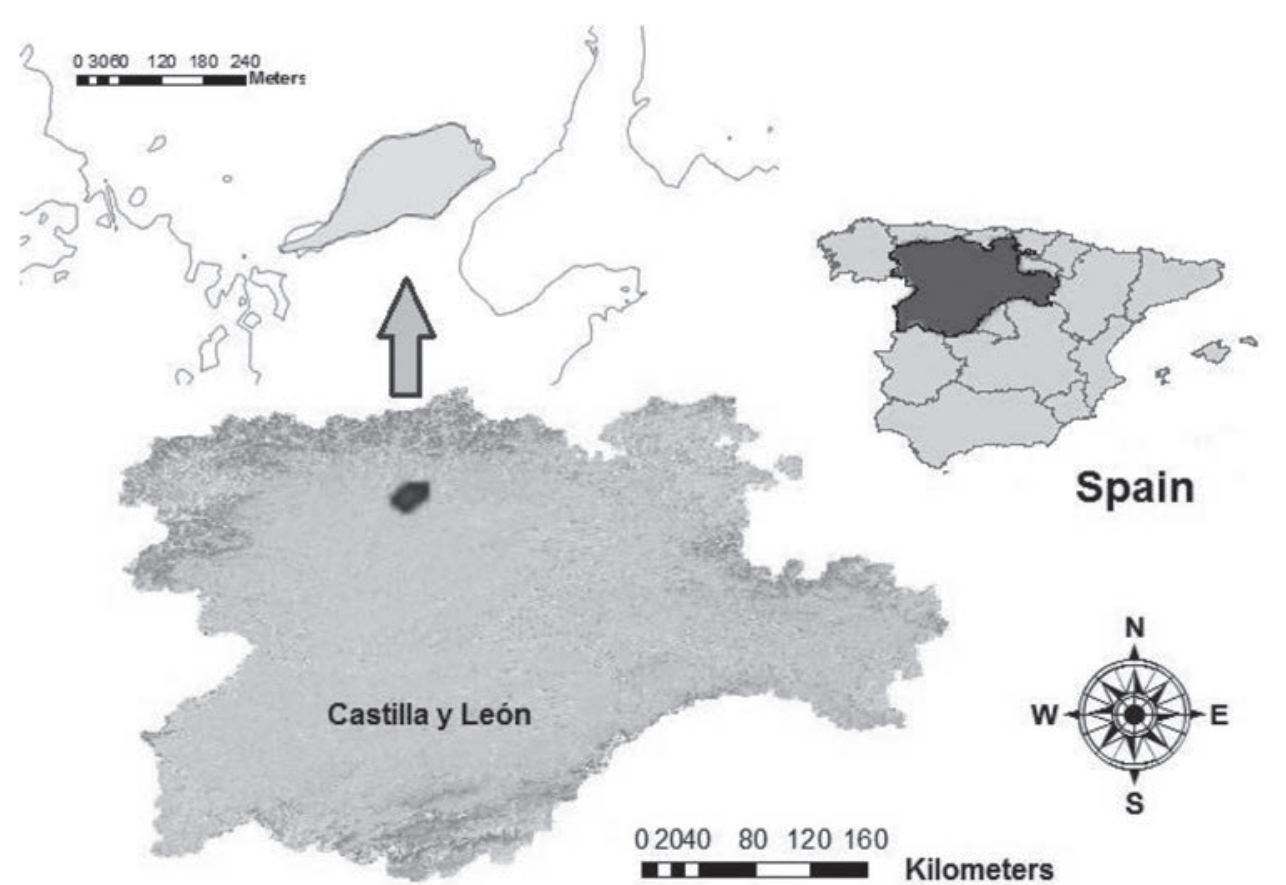

Figure 1. Map of Spain showing the location of Sentiz Lake in a hypsometric data frame. Inset are the level curves around Sentiz Lake. Mapa de España en el que se muestra la localización geográfica de la laguna Sentiz sobre una base hipsométrica. Se incluyen también las curvas de nivel próximas a la laguna Sentiz. 
Aquatic plants are closely related to environmental conditions of lakes and ponds through the root-systems and leaves, which are surrounded in a dense chemical solution compared with terrestrial plants (Heegaard et al., 2001). Macrophyte assemblages are known to be good indicators of environmental disturbances and climate change (Lauridsen et al., 2015). It is thus expected that macrophyte assemblages respond strongly to changes in climate, land use and local conditions.

Macrophytes have an essential role in ecosystem dynamics by modifying the biological structure and the physicochemical properties of the littoral area (Carpenter \& Lodge, 1986). Shallow lakes can exist in two alternative stable states depending on the development of aquatic macrophytes: a clear water state, in which macrophytes are the principal primary producers, and a turbid water state, dominated by phytoplankton (Scheffer et al., 1993). Macrophytes generate positive feedbacks to maintain stable clear water states through sediment stabilization, nutrients uptake and storage, and by providing spatial refuge to macroinvertebrates and zooplankton (Scheffer, 1999). Changes in climate, trophic state, acidity, hydroperiod length, salinity, land use, habitat diversity and sediment composition are able to modify macrophyte assemblages, reducing their diversity and affecting negatively to ecosystem services (Carpenter \& Lodge, 1986; Kissoon et al., 2013).

Mediterranean region is particularly vulnerable to climate change, with greater increases in summer temperatures than other European zones (Peña-Ortiz et al., 2015). In addition, Mediterranean lakes have been historically far less studied than temperate lakes. It is therefore urgent to develop a greater understanding of the environmental drivers of aquatic macrophyte assemblages of shallow Mediterranean lakes, incorporating long term data of both physical and biological parameters.

In this study we analyze the relative influence of climate, land use and local conditions on aquatic macrophye assemblages in a shallow Mediterranean lake. Finally, we expect to find which environmental drivers are responsible for the changes experienced by the aquatic macrophyte assemblages of an Iberian steppe lake during the last twenty years.

\section{METHODS}

\section{Study area}

This study was performed in Sentiz Lake (42³3'22'”N, 5¹2'26'W, altitude: 940 m), a small (maximum area $=4.5 \mathrm{ha}$ ), permanent and shallow (mean depth $=0.8 \mathrm{~m}$ ) water body that suffers significant reduction in water surface area during summer. Sentiz is located in the northwest of Spain in an agricultural landscape (Fig. 1). The dominant lithology consists of low thickness post-Tertiary sediments ('rañas' and alluvial terraces), which superficially cover the great Tertiary detrital deposits.

Climate characterization is referred to as dry temperate Mediterranean with cold, usually rainy winters and hot summers with low rainfall. These characteristics result in significant summer drought.

\section{Macrophyte sampling}

Macrophyte vegetation was sampled once a year in the summer of 1994, 1995, 2002, 2004, 2006 and 2015 along transects. A transect is defined as a line from one shore to the opposite shore at right angles with the longest line. The number of transects was calculated as a function of lake area and shore development (Jénsen, 1977), but these were increased or decreased in-situ, considering the spatial heterogeneity of the macrophyte community. Square sampling units $(0.5 \times 0.5 \mathrm{~m})$ were placed along each profile at distances depending on the homogeneity of the vegetation (for example, in the littoral zone, where community changes with increasing depth are quicker, sampling units were placed closer to each other, whereas in the central area, with more uniform depth, gaps between consecutive samples were increased). Percentage coverage for each species and depth were recorded at each sampling unit. Mean coverage for each species was calculated as the sum of coverages of the species in all sampling units divided by the total number of sampling units used in the lake. For statistical analyses, mean coverage values were transformed into a semi quantitative scale ranging between 1 and $7(1,<1$ \%; 2, 1-3 \%; 3, 3-6 \%, 4, 6-12 \%; 5, 12-25 \%; 6, $25-50 \% ; 7,>50 \%$ ) in order to reliably represent 
the least abundant species (Fernández-Aláez et al., 2016). Finally, Percentage Volume Infested (PVI) was calculated for the whole lake following Canfield et al., (1984):

$$
\text { PVIt }=\sum_{I=1}^{n} \frac{V i H i / Z i}{N}
$$

where PVIt is the PVI of transect $t$; Vi is the percentage of vegetation cover within the sampling unit $\mathrm{i}$; Hi is the maximum plant height in sampling unit $\mathrm{i}$; $\mathrm{Zi}$ is the maximum depth in sampling unit $\mathrm{i} ; \mathrm{N}$ is the total number of sampling units along the transect.

\section{Environmental drivers}

We analyzed 24 environmental variables in relation to climate, land use and local conditions (Table 1) to determine their relative influence on macrophyte community changes in Sentiz Lake.

\section{Climate}

A total of three climate variables were analyzed (Table 1). Mean annual temperature and total annual precipitation were obtained from the Spanish Meteorological Agency (AEMET) from 1973 to 2015. Meanwhile, total annual evapotranspiration was calculated following Thornthwaite (1948).

\section{Land use}

Land use coverage (shore vegetation, croplands, grasslands, peat moss, scrublands and urban) was calculated for 100 and $500 \mathrm{~m}$ buffer radius around the lake through orthophotography obtained from the Agricultural and Technological Institute of Castilla y León (ITACYL) for the years 1977, 2000, 2002, 2004, 2006 and 2014. By using different buffer zones we were able to determine the environmental heterogeneity around the lake (Hanson et al., 2012). In addition, we measured the minimum distance between the croplands and the lake. Finally, land use Diversity and Uniformity were calculated based on the Shannon-Weaver Index (Table 1). Spatial analyses were conducted with ArcGIS 10.2 (ESRI Inc.).

\section{Local conditions}

Water surface area was measured using Digital Satellite Imagery during the summer from 1994 to 2015 using the ETM+ device of Landsat 7 and Landsat 8 Satellites. Mean depth was determined by measuring depth within each sampling unit along the macrophyte profiles during the summer of 2000, 2002, 2004, 2006 and 2015.

A total of seven chemical parameters were measured once a year in the summer of 1994, 1995, 1996, 2000, 2003, 2004, 2005, 2006 and 2015. Conductivity, $\mathrm{pH}$ and dissolved oxygen were measured in-situ using field probes (HACH Model HQ 40 d). Secchi depth was also recorded, but we used the ratio Secchi depth: lake depth instead because of the low water depth (Fernández-Aláez et al., 2016). Several integrated water samples were taken from the whole water column at different locations using a corer (tube of $6 \mathrm{~cm}$ diameter and $1 \mathrm{~m}$ long). The integrated sample was analyzed in order to determine total phosphorus (TP), orthophosphate (SRP), chlorophyll- $a$ and total suspended solids (TSS) (Table 1). Nutrient samples were fixed with mercuric chloride $\left(\mathrm{HgCl}_{2}\right)$ and preserved at $4{ }^{\circ} \mathrm{C}$ until analyses were carried out. All analyses were conducted following standard methods (APHA, 1989).

\section{Statistical analyses}

Environmental drivers (climate, land use and local conditions)

We performed ombrothermic diagrams to detect possible variations in climate patterns. For that purpose, we chose two temporal intervals ranging between 1973-2004 and 2005-2015. The first interval matches the standards for this kind of analyses and the second one is sufficient, in absolute terms, for scientific validation.

The Pearson correlation coefficient between years and environmental parameters was used to detect temporal trends in climate, land use and local conditions. Variables that did not fit normal- 
Table 1. Climate, land use and local variables studied. Mean (X), minimum (Min), maximum (Max) and standard deviation (SD) values for each variable are included. Variables de clima, usos de suelo y características locales estudiadas. Se incluyen los valores medios (X), mínimos (Min), máximos (Max) y las desviaciones estándar (SD) de cada parámetro.

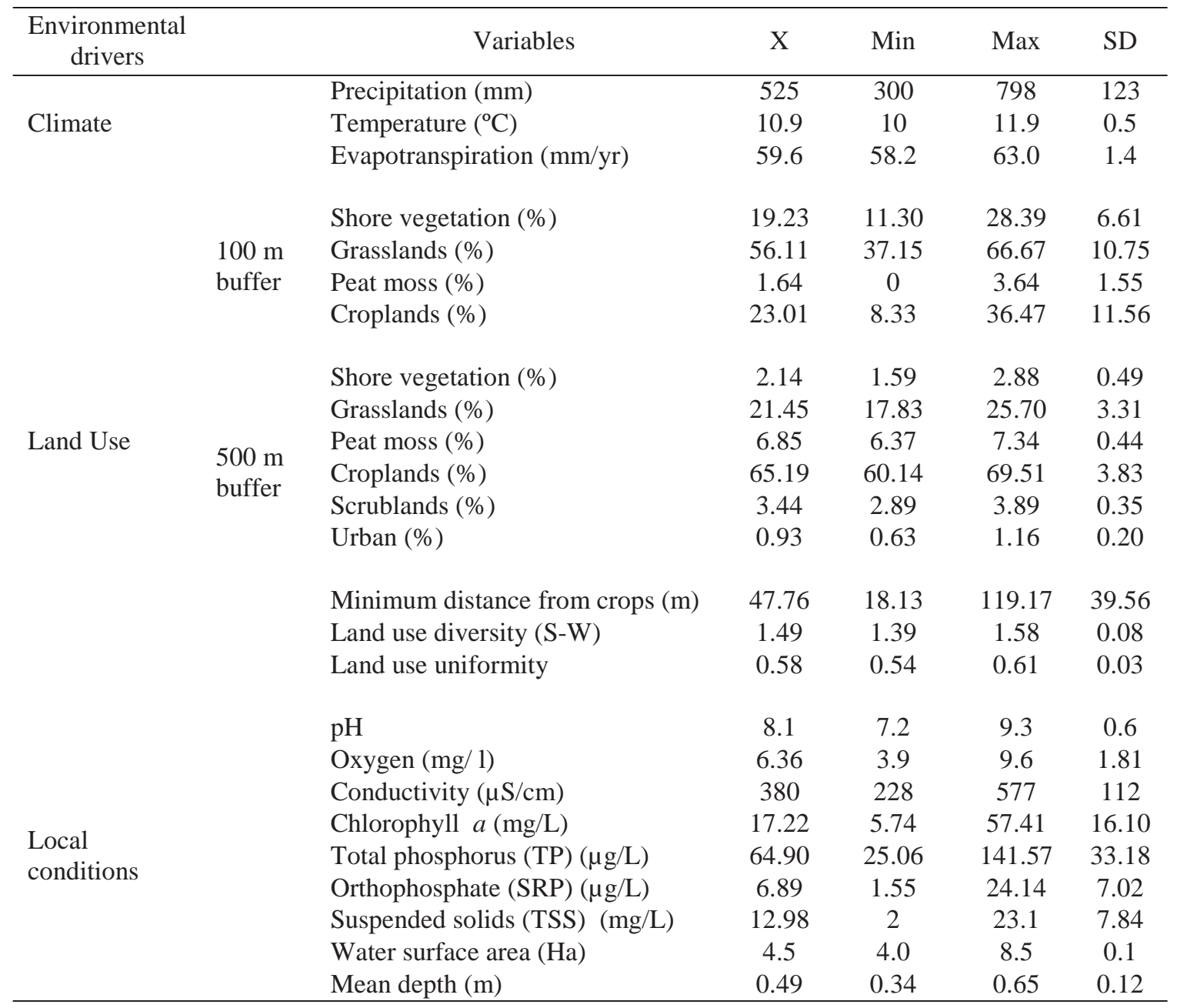

ity were $\log (x)$ or $\log (x+0.1)$ transformed. In the case of percentage variables, the $\arcsin (x / 100)^{1 / 2}$ function was used in order to fit normality. However, for those variables which could not achieve normality, even after log-transformation, the Spearman Coefficient $\left(\mathrm{r}_{\mathrm{s}}\right)$ was calculated. Correlation analyses were also done between groups of environmental drivers and between them (climate, land use and local conditions) and macrophyte growth forms (big helophytes, small helophytes, submerged and floating-leaved hydrophytes and charophytes). For that purpose, we harmonized the available data from AEMET, ITACYL and Landsat with the long-term data of both hydrochemical and biological parameters.

We examined the interannual (1994-2015) patterns of the log-transformed hydrochemical composition (chlorophyll-a, total phosphorus, orthophosphate, suspended solids, conductivity, $\mathrm{pH}$ and oxygen) using Principal Component Analysis (PCA). Previously, we calculated Pearson product moment correlations between hydrochemical variables to identify and remove those showing multicollinearity (Pearson's $p$-value $<0.05$ ).

Pearson and Spearman correlations were calculated with STATISTICA v.8 (StatSoft Inc.), while PCA was performed with CANOCO for Windows 4.5. 


\section{Macrophyte community}

Detrended Correspondence Analysis (DCA) of the species data was used to determine whether linear or unimodal ordination methods should be adopted (ter Braak, 1995). The gradient length of axis 1 exceeded 2.0 standard deviation (SD) units of turnover and thus, a Correspondence Analysis (CA) on coverage data of species was performed in order to assess macrophyte community changes (1994-2015). Similarity in species composition among years was investigated using cluster analysis based on the Bray-Curtis dissimilarity index. We constructed the Bray-Curtis dissimilarity matrix because it ignores joint absences and is suitable for species data (Legendre \& Legendre, 1998). The ANOSIM test was used to verify the statistical significance (90\% confidence) of the cluster analysis. Finally, in order to confirm the previous analyses, we performed a Non-Metric Multidimensional Scaling (NMDS) based on the similarity matrix between years. NMDS contributes to represent the biological variation of the cluster (Free et al., 2006).

In addition, temporal changes of PVI (2000, 2002, 2003, 2004, 2005, and 2015) were explored following the methodology described in Environmental drivers (climate, land use and local conditions).

Detrended Correspondence Analysis (DCA) and Correspondence Analysis (CA) was performed with CANOCO for Windows 4.5, while PRIMER 5 was used to carry out ANOSIM and NMDS.

\section{RESULTS}

\section{Environmental drivers (climate, land use and local conditions)}

The comparison between ombrothermic diagrams for the two time intervals (1973-2004 and 2005-2015) showed an increase in climatic aridity, represented by an accentuated decline in precipitation (Fig. 2). This decrease in precipitation was remarkable in spring and summer, corresponding with the growth period of aquatic macrophytes. Furthermore, a higher degree of seasonality in precipitation patterns, as well as a notable decline
1973-2004

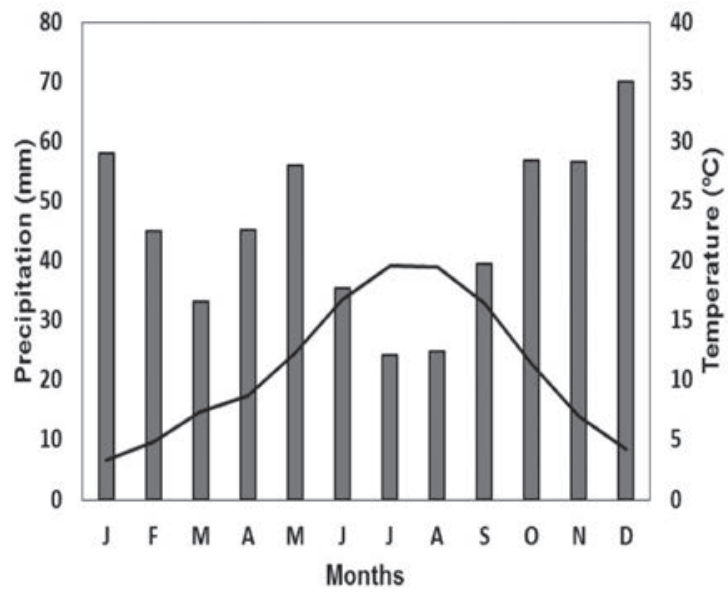

2005-2015

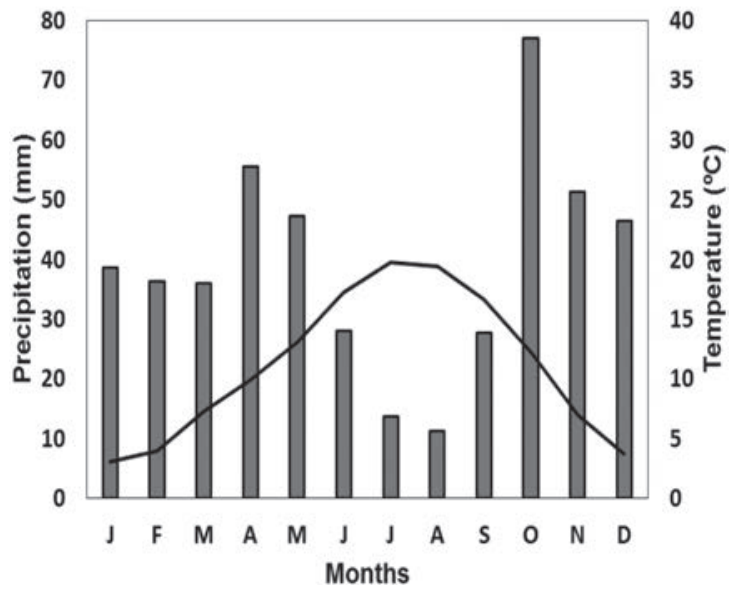

Figure 2. Ombrothermic diagrams for the two intervals (1973-2004 and 2005-2015). Vertical bars represent precipitation $(\mathrm{mm})$ and black lines represent temperature $\left({ }^{\circ} \mathrm{C}\right)$. Diagramas ombrotérmicos para los dos intervalos temporales estudiados (1973-2004 y 2005.2015). Las barras verticales representan la precipitación (mm) y las líneas la temperatura $\left({ }^{\circ} \mathrm{C}\right)$.

of such variable in summer, was observed. There was a significant increase in mean annual temperature with time; nevertheless, we did not find significant changes for total annual precipitation and total annual evapotranspiration (Table 2).

Regarding to the land use near the lake, the most relevant changes from 1977 to 2014 happened around the first $100 \mathrm{~m}$ buffer around Sentiz Lake: shore vegetation and peat moss 
Table 2. Temporal changes of climate, land use and local variables $\left({ }^{*} p<0.05 ; *^{*} p<0.01\right)$. See Table 1 for abbreviations and units. Cambios temporales de las variables de clima, usos de suelo y características locales $\left({ }^{*} \mathrm{p}<0.05 ; * * \mathrm{p}<0.01\right)$. Ver Tabla 1 para las abreviaturas y unidades.

\begin{tabular}{|c|c|c|c|c|c|}
\hline $\begin{array}{c}\text { Environmental } \\
\text { drivers }\end{array}$ & & Variables & $\begin{array}{c}\text { Pearson } \\
\text { coefficient }\end{array}$ & $\begin{array}{c}\text { Spearman } \\
\text { coefficient }\end{array}$ & $p$ \\
\hline \multirow{3}{*}{ Climate } & & Precipitation $(n=43)$ & -0.25 & \multirow[b]{3}{*}{0.22} & \multirow{3}{*}{$*$} \\
\hline & & Temperature $(n=43)$ & 0.38 & & \\
\hline & & Evapotranspiration $(n=13)$ & & & \\
\hline \multirow{13}{*}{ Land Use } & \multirow{6}{*}{$\begin{array}{l}100 \mathrm{~m} \\
\text { buffer }\end{array}$} & Shore vegetation $(n=6)$ & -0.81 & \multirow{6}{*}{0.82} & * \\
\hline & & Grasslands $(n=6)$ & & & * \\
\hline & & Croplands ( $\mathrm{n}=6$ ) & 0.74 & & \\
\hline & & Peat moss $(n=6)$ & -0.83 & & * \\
\hline & & Shore vegetation $(n=6)$ & -0.86 & & * \\
\hline & & Grasslands $(n=6)$ & -0.71 & & \\
\hline & \multirow{7}{*}{$\begin{array}{l}500 \mathrm{~m} \\
\text { buffer }\end{array}$} & Croplands ( $\mathrm{n}=6)$ & 0.70 & & \\
\hline & & Peat moss $(\mathrm{n}=6)$ & 0.33 & & \\
\hline & & Scrublands $(n=6)$ & 0.03 & & \\
\hline & & Urban $(n=6)$ & -0.38 & & \\
\hline & & Min. distance of crops $(n=6)$ & -0.77 & & \\
\hline & & Land use diversity (S-W) $(n=6)$ & -0.71 & & \\
\hline & & Land use uniformity $(n=6)$ & -0.71 & & \\
\hline \multirow{9}{*}{ Local conditions } & & $\mathrm{pH}(\mathrm{n}=9)$ & -0.44 & \multirow{4}{*}{-0.08} & \\
\hline & & Oxygen $(n=9)$ & & & \\
\hline & & Conductivity (n=9) & 0.12 & & \\
\hline & & Chlorophyll $a(n=9)$ & 0.54 & & \\
\hline & & TP $(n=9)$ & & 0.41 & \\
\hline & & $\operatorname{SRP}(n=9)$ & & 0.42 & \\
\hline & & TSS (n=9) & 0.68 & & $*$ \\
\hline & & Lake surface (n=13) & -0.69 & & $* *$ \\
\hline & & Mean depth $(n=5)$ & -0.94 & & $* *$ \\
\hline
\end{tabular}

coverage significantly diminished while grasslands showed a significant increase. For the 500 $\mathrm{m}$ buffer, only shore vegetation showed a significant reduction. At the same time, there was a marked decrease in the minimum distance between croplands and Sentiz Lake, as well as an important reduction in land use diversity from 1.58 to 1.44 bits (Table 2).

We found significant changes for TSS and a significant reduction in lake water surface area and mean depth. Furthermore, although there seemed to be a trend for TP, SRP and chlorophyll- $a$ over the last 20 years, this was not significant ( $p>0.05$; Table 2).
Results from the PCA (Fig. 3) suggested an eutrophication gradient defined by the concentrations of chlorophyll- $a$, TP and SRP. The relative position of samples indicated an increasing influence of eutrophication in more recent years, especially in 2000 and 2006. The most distant years received minimal influence from eutrophication related variables, even though chlorophyll- $a$, TP and SRP showed an occasional reduction in 2015.

\section{Temporal changes in macrophyte community}

The first axis of the CA (49.2 \% of variance) revealed a gradual replacement in the macrophyte 
community of Sentiz Lake (Fig. 4). Macrophyte species typical of low nutrient conditions (Utricularia australis, Myriophyllum alterniflorum, Littorella uniflora and Nitella translucens) defined the community in 1994 and 1995. Afterwards, species typical of low nutrient concentrations and small helophytes (Glyceria fluitans, Juncus articulatus, Alisma plantago-aquatica and Antinoria agrostidea) were replaced by hydrophyte species typical of eutrophic conditions (Ceratophyllum demersum, Potamogeton natans and Potamogeton trichoides) and big helophytes (Typha latifolia, Typha domingensis and Scirpus lacustris).

Cluster analysis distinguished two temporal groups (Fig. 4). The first group included the most distant years (1994 and 1995) and the second one grouped the remaining years (2002, 2004, 2006 and 2015). These groups were supported by the ANOSIM $(\mathrm{R}=1 ; p<0.1)$ and the NMDS ordination (Stress value $=0.01$ ).

In addition, although total PVI seemed to show a rising tendency over the last 20 years, this was not significant $(p>0.05)$.

\section{Macrophyte community and environmental drivers (climate, land use and local conditions)}

We found strong relationships between groups of environmental drivers. TP was closely related to croplands $(\mathrm{r}=0.98 ; p<0.05)$ and to the minimum distance between croplands and Sentiz lake $\left(r_{s}=0.96 ; p<0.05\right)$. At the same time, shore vegetation was negatively correlated to mean annual temperature $\left(\mathrm{r}_{\mathrm{s}}=-0.89 ; p<0.05\right)$, whereas non-significant relationships could be found between climate and local variables.

Furthermore, our results showed strong relationships between environmental drivers and macrophyte growth forms: big helophytes were closely related to croplands $(\mathrm{r}=0.88 ; p<0.05)$ and shore vegetation $(\mathrm{r}=-0.92 ; p<0.05)$. Small helophytes were highly correlated to climate, particularly to total annual precipitation $(\mathrm{r}=-0.89$; $p<0.05$ ), whereas floating-leaved and submerged hydrophytes were highly correlated to local

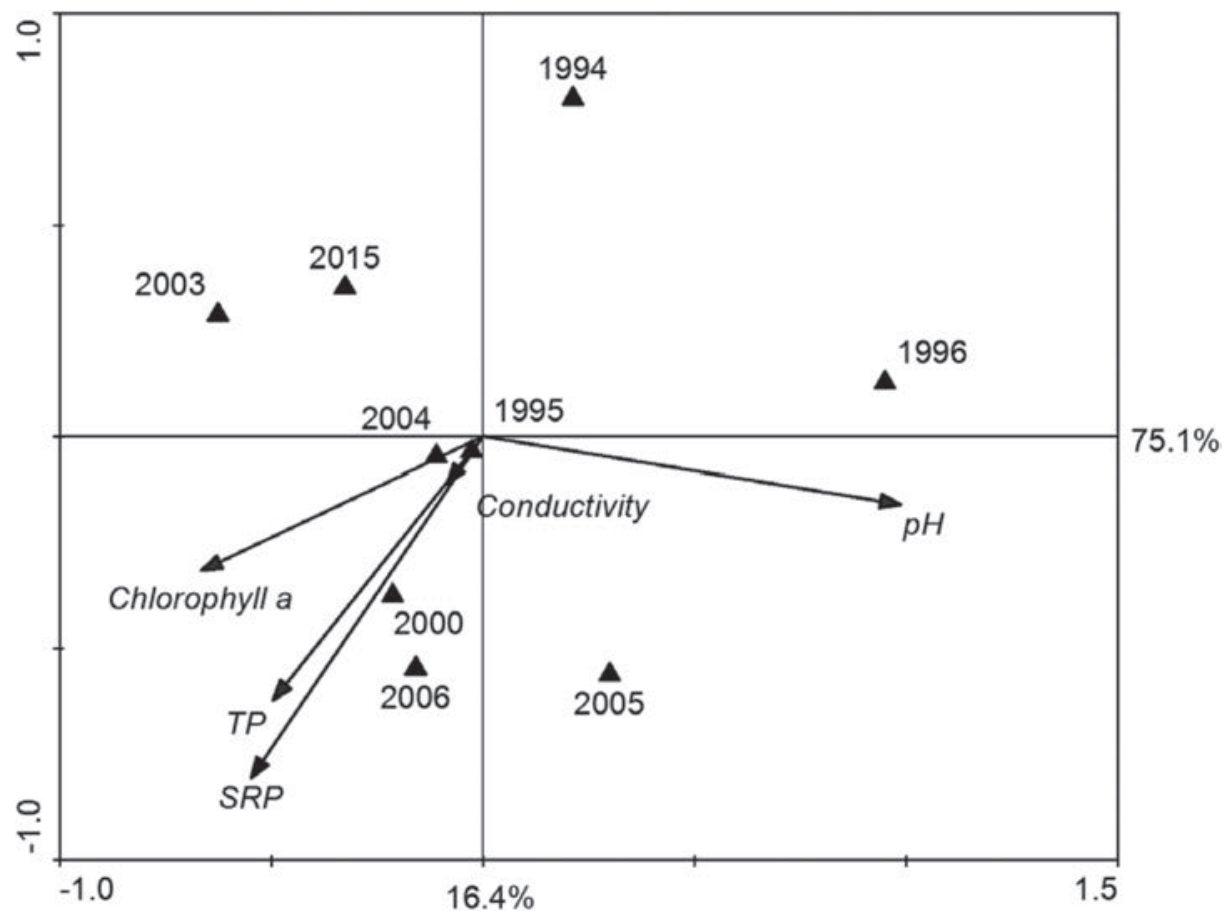

Figure 3. Principal Component Analysis (PCA) for interannual (1994-2015) log-transformed hydrochemical parameters. Variance explained for each axis is included. Análisis de Componentes Principales (ACP) realizado sobre las variables hidroquímicas transformadas logarítmicamente. Se incluye la varianza explicada por cada uno de los ejes. 
conditions (mean depth; $\mathrm{r}=-0.88 ; p<0.05$; TSS; $\mathrm{r}=0.99 ; p<0.05$, respectively).

\section{DISCUSSION}

We found important changes in environmental drivers of aquatic macrophyte assemblages in
Sentiz Lake, a shallow Mediterranean waterbody: mean depth, water surface area and shore vegetation have been reduced while mean annual temperature has risen and grasslands coverage has increased. Macrophyte community has responded concurrently to those changes: submerged macrophytes typical of high nutrient

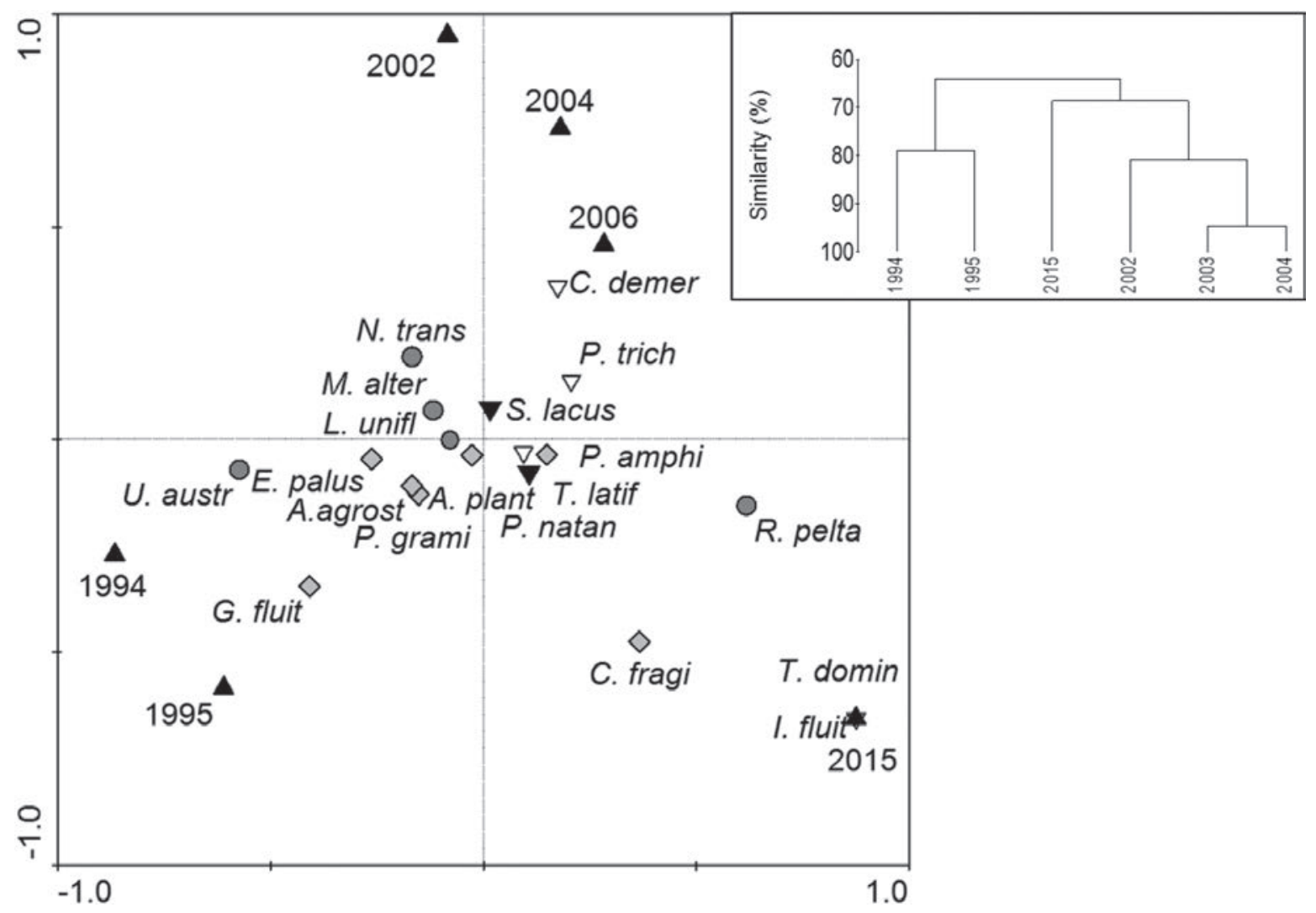

Figure 4. Correspondence Analysis (CA) performed on coverage data of macrophyte assemblages. Abbreviations: U. austr: Utricularia australis; G. fluit: Glyceria fluitans; E. palus: Eleocharis palustris; A. agrost: Antinoria agrostidea; P. grami: Potamogeton gramineus; L. unifl: Littorella uniflora; A. plant: Alisma plantago-aquatica; M. alter: Myriophyllum alterniflorum; N. trans: Nitella translucens; S. lacus: Scirpus lacustris; T. latif: Typha latifolia; P. natan: Potamogeon natans; P. amphi: Polygonum amphibium; P. trich: Potamogeton trichoides; C. demer: Ceratophyllum demersum; R. pelta: Ranunculus peltatus; C. fragi: Chara fragilis; T. domin: Typha domingenis; I. fluit: Isolepis fluitans. Circles represent species typical of low nutrient conditions, diamonds represent species with no apparent preference to low or high nutrient conditions, and white and black down-triangles represent hydrophytes and helophytes typical of high nutrient conditions, respectively (Penning et al., 2008). Inset is the cluster analysis based on the Bray-Curtis dissimilarity index. Análisis Factorial de Correspondencias (AFC) realizado sobre la cobertura de las especies de macrófitos. Abreviaturas: U. austr: Utricularia australis; G. fluit: Glyceria fluitans; E. palus: Eleocharis palustris; A. agrost: Antinoria agrostidea; P. grami: Potamogeton gramineus; L. unifl: Littorella uniflora; A. plant: Alisma plantago-aquatica; M. alter: Myriophyllum alterniflorum; N. trans: Nitella translucens; S. lacus: Scirpus lacustris; T. latif: Typha latifolia; P. natan: Potamogeon natans; P. amphi: Polygonum amphibium; P. trich: Potamogeton trichoides; C. demer: Ceratophyllum demersum; R. pelta: Ranunculus peltatus; C. fragi: Chara fragilis; T. domin: Typha domingenis; I. fluit: Isolepis fluitans. Los círculos representan especies típicas de ambientes oligotróficos, los rombos simbolizan especies eurioicas en relación al estado trófico, y los triángulos invertidos blancos y negros representan, respectivamente, hidrófitos y helófitos típicos de condiciones con una alta concentración en nutrientes (Penning et al., 2008). En el recuadro se incluye el dendrograma basado en el índice de disimilitud de Bray-Curtis. 
levels, floating-leaved hydrophytes and big helophytes have expanded their coverage to the detriment of submerged hydrophytes typical of low nutrient concentrations and small helophytes. Additionally, this study revealed that macrophyte growth forms responded to different environmental controlling factors: submerged and floating-leaved hydrophytes responded to local conditions, whereas big helophytes and small helophytes responded to land use and climate, respectively.

\section{Environmental drivers (climate, land use and local conditions)}

Our study noted potential changes in climate seasonality in the northwest of the Iberian Plateau, mainly because of the expansion of the summer period. This situation led to a significant decrease in water surface area and mean depth of Sentiz Lake. Recent studies have shown an expansion of the summer in Europe and the Mediterranean region between 5 and 12 days per decade during the last 30 years (Peña-Ortiz et al., 2015). At the same time, Peña-Ortiz et al. (2015) recorded increases between 0.5 and $1.2^{\circ} \mathrm{C}$ in mean annual temperature for the Mediterranean region. Those new climate conditions have resulted in extreme droughts (Moss, 2012), water chemistry disturbances and significant decreases in water surface area of shallow Mediterranean lakes and ponds (Ejankowski \& Lenard, 2015).

Shallow Mediterranean lakes are more sensitive to changes in their catchments because of their small size and the high degree of interaction between them and their drainage basin (Szyper \& Goldyn, 2002). In this sense, our results showed considerable changes of land use patterns from 1977 to 2014, particularly in the $100 \mathrm{~m}$ buffer. The expansion of croplands, grasslands and the important reduction of shore vegetation were the most relevant changes.

Furthermore, our study revealed potential changes in the local conditions of Sentiz Lake. For example, mean depth, water surface area and TSS showed significant changes while TP, SRP and chlorophyll- $a$ showed increasing trends. Changes in water chemistry may be related to a host of ecological drivers such as the expansion of croplands, climate change, reduction of the water surface area of the lake and nutrient release from sediment (Moss, 2012; Ejankowski \& Lenard, 2015).

\section{Temporal changes in macrophyte community}

In concordance with Egertson et al. (2004), our investigation revealed that macrophyte community changed from small helophytes ( $G$. fluitans, Eleocharis palustris, A. agrostidea, L. uniflora and $A$. plantago-aquatica) and submerged macrophytes typical of low nutrient conditions ( $U$. australis, $M$. alterniflorum and $N$. translucens) to big helophytes (T. latifolia, T. domingensis and $S$. lacustris), floating-leaved hydrophytes (Polygonum amphibium and $P$. natans) and submerged hydrophytes typical of eutrophic conditions ( $P$. trichoides and $C$. demersum). These macrophyte community changes may be related to the strong reduction of the water surface area (Partanen et al., 2009). Additionally, we suggest that floating-leaved macrophytes could accelerate the natural succession of macrophyte assemblages, releasing nutrients from the sediment in deoxygenated areas of the littoral zone (Feuchtmayr et al., 2009).

The drastic loss of macrophyte species typical of low nutrient concentrations could be related to higher concentrations in TSS, chlorophyll $a$ and phosphorus (Klosowski et al., 2006). According to Egertson et al. (2004), Sentiz Lake would be in an early primary eutrophication stage, in which macrophyte species typical of high nutrient conditions ( $P$. trichoides and $C$. demersum) gradually replace submerged hydrophytes typical of low nutrient conditions ( $M$. alterniflorum). We speculate that species turnover may be the result of the interaction between changes in hydrochemical conditions and the reduction of the water surface area (Hellsten et al., 2006).

\section{Macrophyte community and environmental drivers (climate, land use and local conditions)}

The influence of different environmental drivers on macrophyte communities has already been studied by some authors (Del Pozo et al., 2011; Kissoon et al., 2013; Meier et al., 2015) although 


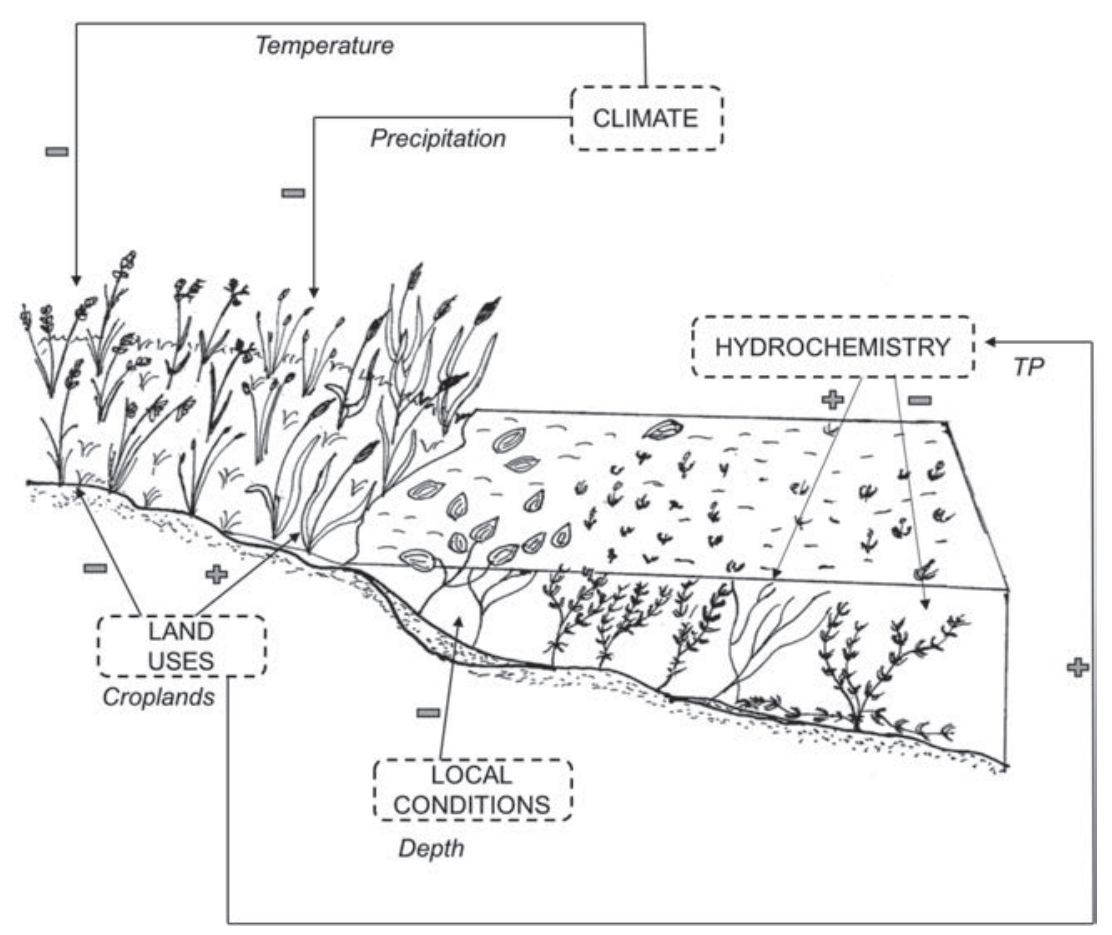

Figure 5. Principal interactions between climate, land use, local conditions and macrophyte growth forms. Add symbols (+) represent positive interactions while subtraction symbols (-) represent negative interactions. Principales interacciones entre las variables climáticas, los usos del suelo, las características locales y las formas de crecimiento de los macrófitos. Los signos + representan interacciones positivas y los símbolos - representan interacciones inversas o negativas.

the final conclusions of these studies are mixed. Particularly, we found that macrophyte growth forms responded to climate, land use and local conditions (Fig. 5). Submerged and floating-leaved hydrophytes responded to local conditions (TSS and mean depth, respectively), while big helophytes and small helophytes responded to land-use changes (croplands and shore vegetation) and climate (total annual precipitation), respectively. Similarly, Álvarez-Cobelas \& Cirujano (2007) found that emergent vegetation responded to different controlling factors at different levels of organization in Mediterranean ponds. Furthermore, as well as in Ejanskowski \& Lenard (2015) and Feld et al. (2016), our study showed strong relationships between climate, land use and local conditions (Fig. 5). For example, TP was closely related to croplands whereas shore vegetation showed a negative correlation with mean annual temperature.

Several surveys analyzed the environmental controlling factors of aquatic macrophytes assem- blages at various locations around the world. For example, the predictors of macrophyte composition in northern European lakes included factors such as lake size (Vestergaard \& Sand-Jensen, 2000) and water chemistry (Heegaard et al., 2001). Similarly, Smith \& Haukos (2002) found that land-use changes determined aquatic plant assemblages in lakes and wetlands located in the Southern Great Plains of the United States, whereas Rolon \& Maltchik (2006) reported that pond area, hydrological fluctuations and water conductivity were the most important predictors of macrophyte community composition in ponds located in Southern Brazil. Our results agree with Del Pozo et al. (2011), Chappuis et al. (2014) and Fernández-Aláez et al. (2016), who revealed that water chemistry, particularly nutrients, and land use are among the most important environmental drivers of macrophyte species composition, distribution and abundance in Mediterranean shallow lakes and ponds. To this regard, the most outstanding result of our study compared to previ- 
ous surveys is that big and small helophytes, as well as submerged and floating-leaved hydrophytes, are determined by different environmental controlling factors.

Overall, this study has improved the knowledge of the environmental controlling factors of aquatic macrophyte assemblages of shallow Mediterranean lakes, incorporating long term data of both physical and biological parameters. It is evident from these results that management efforts aimed at preserving aquatic macrophyte assemblages of shallow Mediterranean lakes should focus not only on local conditions of each lake but also on their watersheds and climate.

\section{ACKNOWLEDGEMENTS}

This research did not receive any specific grant from funding agencies in the public, commercial, or not-for-profit sectors.

\section{REFERENCES}

ADRIAN, R., C.M. O’REILLY, H. ZAGARESE, S.B. BAINES, D.O. HESSEN, W. KELLER, D.M. LIVINGSTON, R. SOMMARUGA, D. STRAILE, E. VAN DONK, G.A. WEYHENMEYER \& M. WINDER. 2009. Lakes as sentinels of climate change. Limnology and Oceanography, 54: 2283-2297. DOI: 10.4319/ lo.2009.54.6_part_2.2273

ÁLVAREZ-COBELAS, M. \& S. CIRUJANO. 2007. Multilevel responses of emergent vegetation to environmental factors in a semiarid floodplain. Aquatic Botany, 87: 49-60. DOI: 10.1016/j.aquabot.2007.03.002

AMERICAN PUBLIC HEALTH ASSOCIATION. 1989. Standard Methods for the Examination of Water and Wastewater. $17^{\mathrm{a}}$ edn. Washington, DC.

BOSCH, N.S., M.A. EVANS, D. SCAVIA \& J.D. ALLAN. 2014. Interacting effects of climate change and agricultural BMPs on nutrient runoff entering Lake Erie. Journal of Great Lakes Research, 40: 581-589. DOI: https://doi.org/10.1016/j.jglr.2014.04.011

CANFIELD, D. E. J., J.V. SHIREMAN, D.E. COLLE, W.T. HALLER, C.E.I. WATKINS \& M.J. MACEINA. 1984. Prediction of chlorophyll a concentrations in Florida lakes: importance of aquatic macrophytes. Canadian Journal of Fisheries and Aquatic Science, 41, 497-501. DOI: https://doi.org/10.1139/f84-059

CARPENTER, S.R. \& D.M. LODGE. 1986. Effects of submersed macrophytes on ecosystem processes. Aquatic Botany, 26: 341-370. DOI: https://doi.org/10.1016/0304-3770(86) 90031-8

CHAPPUIS, E., E. GARCÍA \& E. BALLESTEROS. 2014. Environmental factors explaining the distribution and diversity of vascular macrophytes in highly heterogeneous Mediterranean region. Aquatic Botany, 113: 72-82. DOI: https://doi.org/10.1016/j.aquabot. 2013.11.007

DEL POZO, R., C. FERNÁNDEZ-ALÁEZ \& M. FERNÁNDEZ-ALÁEZ. 2011. The relative importance of natural and anthropogenic effects on community composition of aquatic macrophytes in Mediterranean ponds. Marine and Freshwater Research, 62: 101-109. DOI: https://doi.org/10.1071/MF10125

EGERTSON, C.J., J.A. KOPASKA \& J.A. DOWNING. 2004. A century of change in macrophyte abundance and composition in response to agricultural eutrophication. Hydrobiologia, 524: 145-156.

EJANKOWSKI, W., \& T. LENARD. 2015. Climate driven changes in the submerged macrophyte and phytoplankton community in a hard water lake. Limnologica, 52: 59-66. DOI: https://doi.org/10.1016/j.limno.2015.03.003

FELD, C.K., S. BIRK, D. EME, M. GERISCH, D. HERING, M. KERNAN, K. MAILEHT, U. MISCHKE, I. OTT, F. PLETTERBAUER, S. POIKANE, J. SALGADO, C.D. SAYER, J. VAN WICHELEN \& F. MALARD. 2016. Disentangling the effects of land use and geo-climatic factors on diversity in European freshwater ecosystems. Ecological Indicators, 60: 71-83. DOI: https://doi.org/10.1016/j. ecolind.2015.06.024

FERNÁNDEZ-ALÁEZ， C., M. FERNÁNDEZ-ALÁEZ, F. GARCÍA-CRIADO \& J. GARCÍA-GIRÓN. 2016. Environmental drivers of aquatic macrophyte assemblages in ponds along an altitudinal gradient. Hydrobiologia. DOI: 10.1007/s10750-016-2832-5. 
FEUCHTMAYR, H., R. MORAN, K. HATTON, L. CONNOR, T. HEYES, B. MOSS, I. HARVEY \& D. ATKINSON. 2009. Global warming and eutrophication: effects on water chemistry and autotrophic communities in experimental hypertrophic shallow lake mesocosms. Journal of Applied Ecology, 46: 713-723. DOI: 10.1111/j.1365-2664.2009. 01644.X

FREE, G., R. LITTLE, D. TIERNEY, K. DONNELLY \& R. CARONI. 2006. A reference Based Typology and Ecological Assessment System for Irish Lakes - Preliminary Investigations. Environmental Protection Agency. Wexford. Ireland.

HANSON, M.A., B.R. HERWIG, K.D. ZIMMER, S. FIEBERG, R. VAUGHN, R.G. WRIGHT \& J.A YOUNK. 2012. Comparing effects of lake- and watershed-scale influences on communities of aquatic invertebrates in shallow lakes. PLOS ONE. DOI: 101371/journal.pone.0044644.

HEEGAARD, E., H.H. BIRKS, C.E. GIBSON, S.J. SMITH \& S. WOLFE-MURPHY. 2001. Species-environmental relationships of aquatic macrophytes in Northern Ireland. Aquatic Botany, 70: 175-223. DOI: https://doi.org/10. 1016/S0304-3770(01)00161-9

HELLSTEN, S., A. KETO, M. SUORANIEMI \& S. PARTANEN. 2006. Long-term changes in the aquatic vegetation of Lake Päijänne, Southern Finland. Limnologica, 29: 1167-1173.

JÉNSEN, S. 1977. An objective method for sampling the macrophyte vegetation in lakes. Vegetatio, 33: 107-118.

KISSOON, L.T.T., D.L. JACOB, M.A. HANSON, B.R. HERWIG, S.E. BOWE, \& M.L. OTTE. 2013. Macrophytes in shallow lakes: Relationships with water, sediment and watershed characteristics. Aquatic Botany, 109: 39-48. DOI: https://doi.org/10.1016/j.aquabot. 2013.04.001

KLOSOWSKI, S., G.H. TOMASZEWICZ \& H. TOMASZEWICZ. 2006. The expansion and decline of charophyte communities in lakes within the Sejny Lake District (north-eastern Poland) and changes in water chemistry. Limnologica, 36: 234-240. DOI: https://doi.org/10.1016/j.limno.2006.07.001

LAURIDSEN, T.L., E. JEPPESEN, S.A.J. DECLERCK, L. DE MEESTER, J.M. CONDE-PORCUNA, W. ROMMENS \& S. BRUCET. 2015. The importance of environmental variables for submerged macrophyte community assemblage and coverage in shallow lakes: differences between northern and southern Europe. Hydrobiologia, 744: 49-61. DOI: 10.1007/s10750-014-2055-6

LEGENDRE, P., \& LEGENDRE, L. 1998. Numerical Ecology. Elsevier.

LOH, J. \& M. WACKERNAGEL. 2004. Informe planeta vivo. WWF.

MEIER, S., M. LUOTO \& J. SOININEN. 2015. The effects of local, buffer zone and geographical variables on lake plankton metacommunities. Hydrobiologia, 743: 175-188. DOI: $10.1007 /$ s10750-014-2034-y

MOSS, B. 2012. Cogs in the endless machine: Lakes, climate change and nutrient cycles: A review. Science of the Total Environment, 434: 130-142. DOI: https://doi.org/10.1016/ j.scitotenv.2011.07.069

ORMEROD, S.J., M. DOBSON, A.G. HILDREW \& C.R. TOWNSEND. 2010. Multiple stressors in freshwater ecosystems. Freshwater Biology, 55: 1-4. DOI: 10.1111/j. 1365-2427.2009.02395.X

PARMESAN, C. \& G. YOHE. 2003. A globally coherent fingerprint of climate change impacts across natural systems. Nature, 421: 37-42. DOI:10.1038/nature01286

PARTANEN, S., M. LUOTO \& S. HELLSTEN. 2009. Habitat level determinants of emergent macrophyte occurrence, extension, change in two large boreal lakes in Finland. Aquatic Botany, 90: 261-268. DOI: https://doi.org/10. 1016/j.aquabot.2008.11.001

PENNING, W.E., M. MJELDE, B. DUDLEY, S. HELLSTEN, J. HANGANU, A. KOLADA, M. VAN DER BERG, S. POIKANE, G. PHILLIPS, N. WILLBY \& F. ECKE. 2008. Classifying aquatic macrophytes as indicators of eutrophication in European lakes. Aquatic Ecology, 42: 237-251. DOI: http://dx.doi.org/ 10.1007/s10452-008-9182-y

PEÑA-ORTIZ, C., D. BARRIOPEDRO \& R. GARCÍA-HERRERA. 2015. Multidecadal 
Variability of the Summer Lengh in Europe. Journal of Climate, 28: 5375-5388. DOI: http://dx.doi.org/10.1175/JCLI-D-14-00429.1

ROLON, A.S. \& L. MALTCHIK. 2006. Environmental factors as predictor of aquatic macrophyte richness and composition in wetlands of southern Brazil. Hydrobiologia, 556: 221-231. DOI: 10.1007/s10750-005-1364-1

SCHEFFER, M., S.H. HOSPER, M.L. MEIJER, B. MOSS \& E. JEPPESEN. 1993. Alternative equilibria in shallow lakes. Trends in Ecology and Evolution, 8: 275-279. DOI: https://doi. org/10.1016/0169-5347(93)90254-M

SCHEFFER, M. 1999. The effect of aquatic vegetation on turbidity: How important are the filter feeders? Hydrobiologia, 408: 307-316.

SMITH, L.M. \& D.A. HAUKOS. 2002. Floral diversity in relation to playa wetland area and watershed disturbance. Conservation Biology, 16: 964-974. DOI: 10.1046/j.1523-1739.2002. 00561.X

SZYPER, H. \& R. GOLDYN. 2002. Role of catchment area in the transport of nutrients to lakes in the Wielkopolska National Park in Poland. Lakes and Reservoirs: Research and Management, 7: 25-33.

THORNTHWAITE, C.W. 1948. An approach toward a rational classification of climate. Geographical Review, 38: 55-94.

VESTERGAARD, O. \& K. SAND-JENSEN. 2000. Aquatic macrophyte richness in Danish lakes in relation to alkalinity, transparency and lake area. Canadian Journal of Fisheries and Aquatic Sciences, 57: 2022-2031. DOI: https://doi.org/10.1139/f00-156 